\title{
Chronic Stress Differentially Affects Antioxidant Enzymes and Modifies the Acute Stress Response in Liver of Wistar Rats
}

\author{
J. DJORDJEVIC ${ }^{1}$, A. DJORDJEVIC ${ }^{1}$, M. ADZIC ${ }^{1}$, A. NICIFOROVIC ${ }^{1}$, M. B. RADOJCIC ${ }^{1}$ \\ ${ }^{1}$ Laboratory of Molecular Biology and Endocrinology, VINCA Institute of Nuclear Sciences, \\ P.O.Box-522-MBE090, 11001 Belgrade, Serbia
}

Received July 17, 2009

Accepted November 25, 2009

On-line April 20, 2010

\begin{abstract}
Summary
Clinical reports suggest close interactions between stressors, particularly those of long duration, and liver diseases, such as hepatic inflammation, that is proposed to occur via reactive oxygen species. In the present study we have used 21-day social isolation of male Wistar rats as a model of chronic stress to investigate protein expression/activity of liver antioxidant enzymes: superoxide dismutases (SODs), catalase (CAT), glutathione peroxidase (GPx) and glutathione reductase (GLR), and protein expression of their upstream regulators: glucocorticoid receptor (GR) and nuclear factor kappa B (NFkB). We have also characterized these parameters in either naive or chronically stressed animals that were challenged by $30-\mathrm{min}$ acute immobilization. We found that chronic isolation caused decrease in serum corticosterone (CORT) and blood glucose (GLU), increase in NFkB signaling, and disproportion between CuZnSOD, peroxidases (CAT, GPX) and GLR, thus promoting $\mathrm{H}_{2} \mathrm{O}_{2}$ accumulation and prooxidative state in liver. The overall results suggested that chronic stress exaggerated responsiveness to subsequent stressor at the level of CORT and GLU, and potentiated GLR response, but compromised the restoration of oxido-reductive balance due to irreversible alterations in MnSOD and GPx.
\end{abstract}

\section{Key words}

Stress • Liver • Antioxidant enzymes • Nuclear factor kappa B • Glucocorticoid receptor

\section{Corresponding author}

Marija Radojcic, senior research fellow, Laboratory of Molecular Biology and Endocrinology, VINCA Institute of Nuclear Sciences, P.O.Box-522-MBE090, 11001 Belgrade, Serbia. Fax +381 (11) 344-0100. E-mail: marija@vinca.rs

\section{Introduction}

Liver exhibits one of the highest antioxidant enzyme capacity in the body due to its major metabolic roles including glycogen storage, decomposition of red blood cells, plasma protein synthesis, detoxification and others (Navarro-Arevalo and Sanchez-Del-Pino 1998). This organ also plays indispensable role in the adaptive response to neuroendocrine stress, when its anabolic activity provides energy-rich compounds, such as glucose and lipids, necessary for organism's adaptation (Sapolsky et al. 2000). The adaptive liver response is triggered by stress-induced elevation of serum glucocorticoids (GCs) which among other actions stimulate liver gluconeogenesis (McKay and Cidlowsky 2000). However, altered levels of GCs are also known to promote the toxicity of oxygen radical generators, through increase in the basal level of reactive oxygen species (ROS) produced by the cells (McIntosh et al. 1998). Genomic effects of GCs are mediated through the glucocorticoid receptor (GR). In addition to GR, another redox-sensitive transcriptional factor, nuclear factor kappa B (NFkB) is considered as important stress sensor playing crucial role in determining cellular fate during oxidative stress (Martindale and Holbrook 2002). NFkB is known to be activated by ROS and its activation leads to the transcriptional activation of numerous stressresponse genes including antioxidant enzymes (Kim et al. 1994, Wan et al. 1994, Xu et al. 1999, Zhou et al. 2001, Rojo et al. 2004). The reviewed literature suggests that under neuroendocrine stress, antioxidant enzymes are regulated by interplay of GCs signals via GR and signals from NFkB pathway (De Bosscher et al. 2003, Antras- 
Ferry et al. 1997), both altering cellular antioxidant enzyme levels and thus final level of cellular ROS. A disproportion in intensity of these signals, particularly under the chronic neuroendocrine stress, may result in a shift of cellular redox state towards oxidation (Finkel and Holbrook 2000).

ROS are kept at physiologically optimal levels by antioxidant defense systems, including the array of antioxidant enzymes: cellular and mitochondrial superoxide dismutases (copper/zinc-dependent (CuZnSOD) and $\mathrm{Mn}^{2+}$-dependent superoxide dismutase (MnSOD)), catalase (CAT), glutathione peroxidase (GPx) and glutathione reductase (GLR), and non-enzymatic antioxidants such as glutathione (GSH). MnSOD and $\mathrm{CuZnSOD}$ convert superoxide anions to $\mathrm{H}_{2} \mathrm{O}_{2}$, which is then transformed to water by CAT or GPx. Glutathione reductase (GLR) plays an essential role in cell defense against reactive oxygen metabolites by sustaining the reduced status of glutathione, which reducing power is also necessary for GPx activity. An alteration of the normal redox balance can alter cell signalling pathways in hepatocytes and may thus be an important mechanism in mediating the pathogenesis of many liver diseases.

Based on these presumptions in the current study we have exploited 21 days isolation of male Wistar rat as a model of chronic neuroendocrine stress of low CORT (Sanchez et al. 1998, Malkesman et al. 2006) to investigate liver GR, NFkB and antioxidant enzyme capacity under this conditions. The antioxidant enzyme capacity was further used as indirect measure of potentially permanent ROS imbalance generated by the chronic stress. We have also characterized these parameters in either naive or chronically stressed animals that were challenged by $30-$ min acute immobilization as a high CORT stressor (Garcia et al. 2000) that induces normal stress response (McEwen 1998). The working hypothesis tested in this study is that chronic psychosocial stress may permanently alter antioxidant enzyme capacity in the liver and thus compromise its ability to generate adaptive response to subsequent stressor.

\section{Material and Methods}

\section{Animal care and treatment}

All experiments were performed in adult (3 months old) Wistar male rats (body mass 330-400 g), housed four per standard size cage and offered food and water ad libitum. Light was kept on, between 07:00 am and 07:00 pm, and room temperature (RT) was kept at $20 \pm 2{ }^{\circ} \mathrm{C}$. All animal procedures were approved by the Ethical Committee for the Use of Laboratory Animals of the VINCA Institute of Nuclear Sciences, according to the guidelines of the EU registered Serbian Laboratory Animal Science Association (SLASA). For the purpose of the experiment, animals were divided in four groups: group I consisted of unstressed animals (control group); group II animals were exposed to acute immobilization for $30 \mathrm{~min}$ (immobilization stress was induced as described by Kvetňanský and Mikulaj 1970); group III animals were subjected to chronic isolation stress, by housing them individually for 21 days; group IV was exposed to chronic isolation for 21 days followed by 30-min immobilization. We performed three independent measurements from two separate groups each consisting of five animals (total number of animals was 10 per experimental group).

\section{Determination of serum corticosterone and blood glucose} level

Animals were sacrificed immediately after the termination of the stress procedure by decapitation with a guillotine (Harvard-Apparatus, USA). Blood was immediately collected and serum was prepared by $15 \mathrm{~min}$ centrifugation at $3000 \mathrm{rpm}$. Serum corticosterone level was determined using the OCTEIA Corticosterone EIA kit according to manufacturer's instructions (American Laboratory Products Co.). Calibrators, controls and diluted samples were loaded on a 96-well plate coated with a polyclonal anti-CORT antibody, along with HRPlabeled CORT. The plate was incubated overnight at $4{ }^{\circ} \mathrm{C}$, washed, and color was developed using chromogenic substrate. The reaction was stopped by adding $\mathrm{HCl}$. Absorbance at $450 \mathrm{~nm}$ (reference $650 \mathrm{~nm}$ ) was determined by microplate reader (Wallac, VICTOR ${ }^{2}$ 1420, PerkinElmer). CORT concentration (ng/ml) was determined using standard curve, which was prepared on semi-log graph using measured values of kit calibrators, in the concentration range of $1.7-176 \mathrm{ng} / \mathrm{ml}$. To obtain concentration of CORT in each sample the values read from the curve were multiplied by the dilution factor. Blood glucose level was determined by Accutrend strips.

\section{Isolation of tissue}

After sacrifice, livers of animals from each group were perfused in situ, carefully excised and kept frozen $\left(-70{ }^{\circ} \mathrm{C}\right)$ until further analyses. After a swift thawing livers were weighed and homogenized $(1: 4=$ 
tissue weight:vol) in $10 \mathrm{mM}$ TrisHCl pH 7.4 buffer (containing $0.32 \mathrm{M}$ sucrose, $5 \mathrm{mM} \mathrm{MgCl}_{2}$ and $10 \mathrm{mM}$ PMSF) at $4{ }^{\circ} \mathrm{C}$, using 20 strokes of Potter-Elvehjem homogenizer. Homogenate was lysed by ice-cold $1 \%$ Triton X-100 for $2 \mathrm{~h}$ (with frequent vortexing) in the same buffer and lysate was centrifuged at 12,000 rpm for 15 min at $4{ }^{\circ} \mathrm{C}$ to obtain supernatant which was used as a whole cell extract. The protein concentration in the samples was analyzed according to Lowry et al. (1951).

Western blot analysis of antioxidant enzymes and transcription factors in liver

Whole cell extracts were prepared with denaturing buffer according to Laemmli (1970), boiled for $5 \mathrm{~min}$ at $100{ }^{\circ} \mathrm{C}$, and $60 \mu \mathrm{g}$ of protein were subjected to electrophoresis on $10 \%$ sodium dodecyl sulfatepolyacrylamide gel (SDS-PAGE). Subsequently, proteins were transferred onto PVDF membrane (Immobilon-P membrane, Millipore) using a blot system (Transblot, BioRad). The membranes were incubated in blocking buffer: phosphate buffer saline (PBS) containing $5 \%$ milk for $1 \mathrm{~h}$ at room temperature, and thereafter probed overnight at $4{ }^{\circ} \mathrm{C}$ with specific primary antibodies diluted in PBS with $2.5 \%$ milk and $0.1 \%$ Tween 20. After washing three times in PBST membranes were incubated with respective secondary antibody for $2 \mathrm{~h}$ at $4{ }^{\circ} \mathrm{C}$, washed three times, soaked in enhanced chemiluminescence reagent (ECL, Pierce) and exposed to X-ray film (Agfa). Rabbit polyclonal anti- $\beta$-actin (ab8227, Abcam) was used to detect $\beta$-actin, as a loading control, and anti-MnSOD (Stressgen), anti-CuZnSOD (Stressgen), anti-catalase (Calbiochem), anti-GPx (Santa Cruz Biotechnology), anti-glutathione reductase (Santa Cruz Biotechnology), anti-NFkB (Santa Cruz Biotechnology) and anti-GR (Santa Cruz Biotechnology) were used to detect MnSOD, CuZnSOD, CAT, GPx, GLR, NFkB and GR, respectively. Blots were developed with the secondary goat anti-rabbit IgG-HRP conjugate. The quantification of the blots was performed by Image $\mathrm{J}$ PC software analysis.

\section{Liver antioxidant enzymatic activities}

Total SOD activity was measured according to McCord and Fridovich (1969), by following the inhibition of cytochrome $\mathrm{c}$ reduction. SOD activity was expressed as $\mathrm{U} / \mathrm{mg}$ of protein, where unit is defined as amount of protein that inhibits $50 \%$ of cytochrome c reduction. Catalase activity was determined by the method of Claiborne (1985), using $\mathrm{H}_{2} \mathrm{O}_{2}$ as substrate. The disappearance of $\mathrm{H}_{2} \mathrm{O}_{2}$ was determined spectrophotometrically at $240 \mathrm{~nm}$. Catalase activity was also expressed as U/mg of protein, where one unit represents the amount of protein needed for degradation of $1 \mu \mathrm{mol}$ of $\mathrm{H}_{2} \mathrm{O}_{2}$ per minute. The activity of glutathione peroxidase was assayed at $340 \mathrm{~nm}$, using t-butyl hydroperoxide and GSH as substrates according to Maral et al. (1977), and the activity was expressed as U/mg of protein. Glutathione reductase activity was measured according to Glatzle et al. (1974) by detection of the oxidation of NADPH used for reduction of GSSG, and the activity was again expressed as U/mg of protein. For the GPx and GLR one unit represents 1 nmol NADPH per minute.

\section{Statistical analysis of data}

Data are presented as mean \pm SEM from three independent measurements of samples obtained from two separate groups each consisting of five animals. For establishing significant differences the data were analyzed by the one-way ANOVA followed by the Tukey post-hoc test. Values were considered statistically significant at $p<0.05$ level. In order to simplify the presentation of data all statistically significant differences are given as $\mathrm{p}<0.05$ (including $\mathrm{p}<0.01$ and $\mathrm{p}<0.001$ ).

\section{Results}

As shown in Table 1, the acute (30 $\mathrm{min})$ immobilization resulted in 4.6 fold increase of serum corticosterone level, accompanied by increased level of blood glucose $(\mathrm{p}<0.05)$ in respect to controls. On the contrary, chronic social isolation for 21 days led to significant decrease of both CORT and GLU levels (Table 1). When the chronically stressed animals were subsequently subjected to acute immobilization (i.e. combined stress), serum CORT and blood GLU increased to similar levels as those observed under acute stress (Table 1) with 9.3 fold CORT increase in respect to chronically stressed animals.

The quantification of protein expression of MnSOD and CuZnSOD showed significant increase of both proteins after acute stress in respect to controls (Fig. 1) which was in accordance with elevated total SOD enzymatic activity (Table 2). After chronic isolation or the combined stress protein expression of CuZnSOD was increased $(\mathrm{p}<0.05)$, while MnSOD remained unaffected (Fig. 1). Total SOD activity was also increased under both stress conditions (Table 2). 
Table 1. Serum corticosterone (CORT) and blood glucose (GLU) in control and stressed animals in concentration units or fold ratio.

\begin{tabular}{|c|c|c|c|c|c|c|c|}
\hline Stress & Control & Acute & Chronic & Combined & & $\begin{array}{l}\text { acute } v s . \\
\text { control }\end{array}$ & $\begin{array}{l}\text { combined } \\
\text { vs. chronic }\end{array}$ \\
\hline $\begin{array}{l}\text { CORT } \\
(n g / m l)\end{array}$ & $136.8 \pm 44.5$ & $626.9 \pm 107.1 *$ & $64.7 \pm 28.3^{*}$ & $601.2 \pm 89.7^{*}$ & \multirow{2}{*}{$\begin{array}{l}\text { fold } \\
\text { increase }\end{array}$} & 4.6 & 9.3 \\
\hline $\begin{array}{l}\text { GLU } \\
(\mathrm{mmol} / \mathrm{l})\end{array}$ & $5.7 \pm 0.8$ & $8.1 \pm 0.7^{*}$ & $3.4 \pm 0.7^{*}$ & $7.2 \pm 0.8^{*}$ & & 1.4 & 2.1 \\
\hline
\end{tabular}

Data are means $\pm \mathrm{SEM}, * \mathrm{p}<0.05$.

Table 2. Antioxidant enzyme activities in control and stressed animals.

\begin{tabular}{lllll}
\hline $\begin{array}{l}\text { Enzyme activity } \\
\text { (U/mg protein) }\end{array}$ & Control & Acute & Chronic & Combined \\
\hline SOD & $66.48 \pm 0.77$ & $77.93 \pm 1.25^{*}$ & $77.04 \pm 2.04^{*}$ & $81.91 \pm 2.64^{*}$ \\
Catalase & $322.11 \pm 3.98$ & $374.71 \pm 4.42^{*}$ & $320.81 \pm 5.18$ & $384.54 \pm 4.85^{*}$ \\
GPX & $36.42 \pm 1.30$ & $42.03 \pm 1.10^{*}$ & $37.76 \pm 1.69$ & $38.46 \pm 2.30$ \\
GLR & $21.35 \pm 0.62$ & $22.69 \pm 0.46$ & $18.09 \pm 0.65^{*}$ & $26.22 \pm 0.89 *$ \\
\hline
\end{tabular}

Data are means $\pm \mathrm{SEM}, * \mathrm{p}<0.05$.
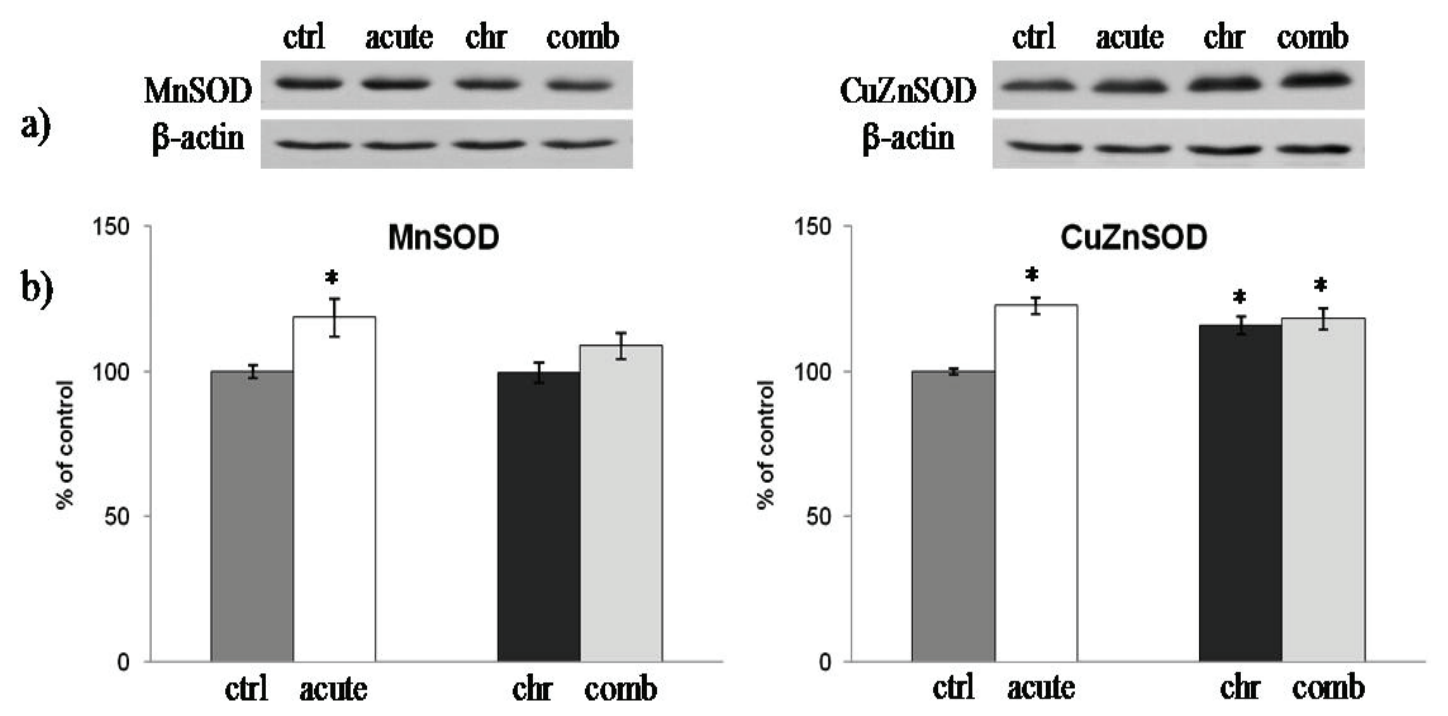

Fig. 1. a) Representative Western blots of Mn-superoxide dismutase (MnSOD) and CuZn-superoxide dismutases (CuZnSOD) in whole cell extract of liver of stressed Wistar rats. b) Relative quantification of MnSOD and CuZnSOD protein expression in whole cell extract obtained from two separate experiments each performed in triplicates. Data are presented as mean $\pm \mathrm{SEM}, * \mathrm{p}<0.05$.

Catalase and glutathione peroxidase also responded to 30-min immobilization stress with increased protein expression (Fig. 2), as well as, with the respective elevation in their activity in respect to control (Table 2). In terms of chronic stress, neither protein expression nor enzymatic activity of these two proteins were altered, while after subsequent acute stress only CAT was induced (Fig. 2, Table 2). Under acute stress, both protein expression (Fig. 2) and enzymatic activity (Table 2) of glutathione reductase (GLR) remained unchanged. However, they were markedly decreased by the chronic stress $(p<0.05)$, but significantly elevated by the combined stress (Fig. 2, Table 2).

Protein expression of NFkB and GR revealed 
a)
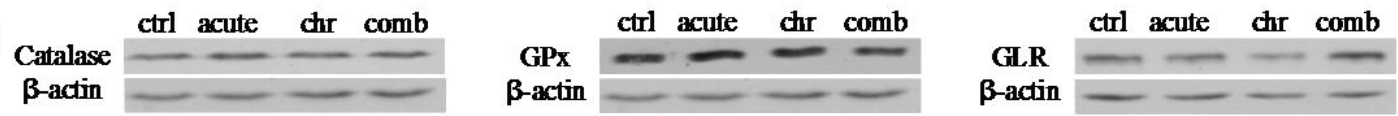

b)
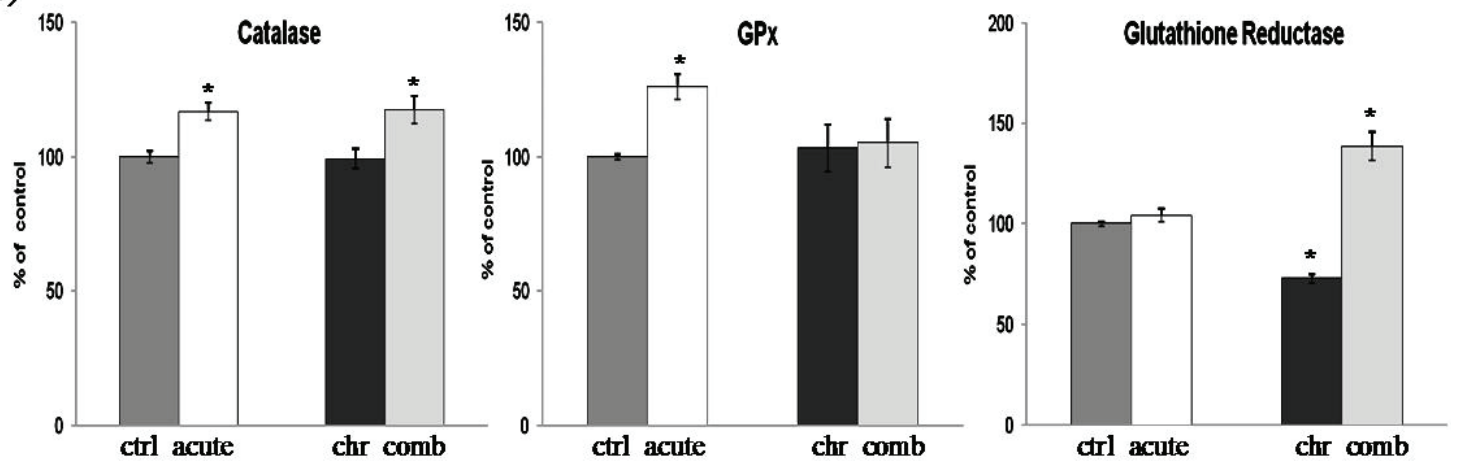

Fig. 2. a) Representative Western blots of catalase, glutathione peroxidase (GPx) and glutathione reductase in whole cell extract of liver of stressed Wistar rats. b) Relative quantification of CAT, GPX and GLR protein expression in whole cell extract obtained from two separate experiments each performed in triplicates. Data are presented as mean $\pm \mathrm{SEM}, * \mathrm{p}<0.05$.
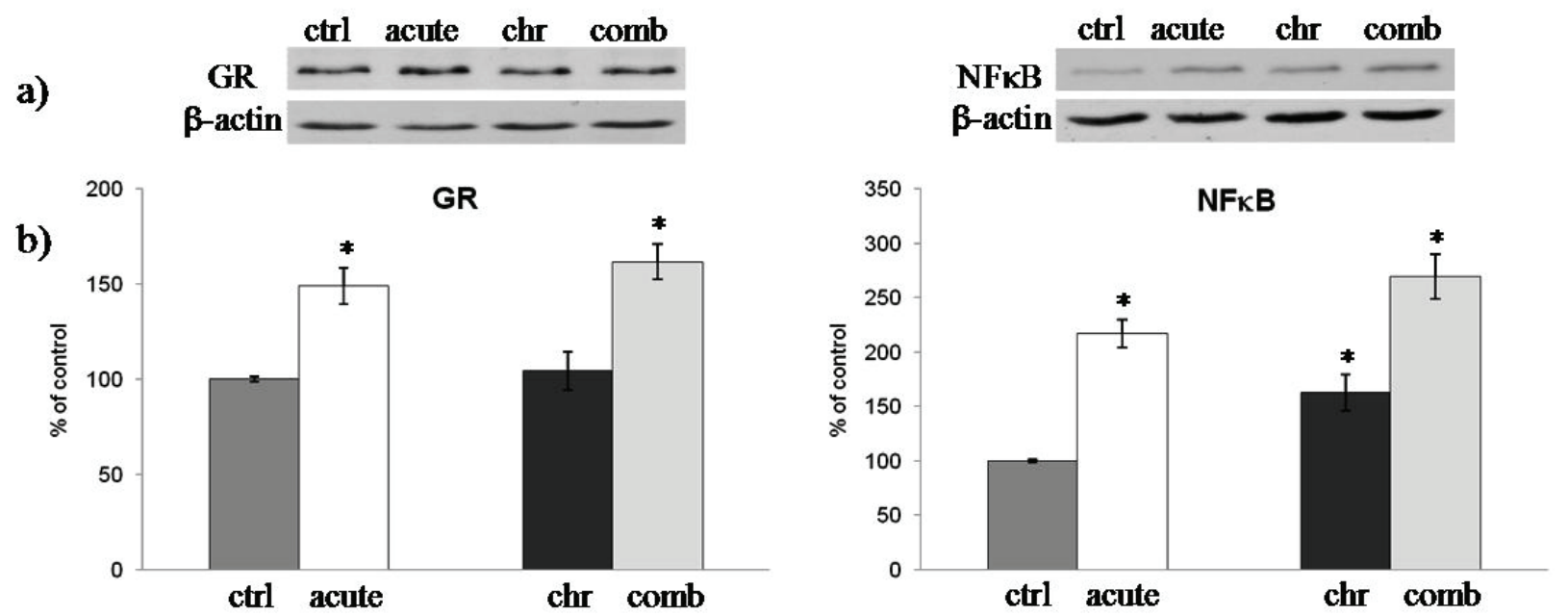

Fig. 3. a) Representative Western blots of glucocorticoid receptor (GR) and nuclear factor kappa $B$ (NFkB) in whole cell extract of liver of stressed Wistar rats. b) Relative quantification of GR and NFkB protein expression in whole cell extract obtained from two separate experiments each performed in triplicates. Data are presented as mean $\pm \mathrm{SEM}, * \mathrm{p}<0.05$.

their significant induction in response to acute stress, with relative level of NFkB exhibiting markedly higher induction then GR (Fig. 3). NFkB was also elevated, but to a lesser extent under chronic stress $(\mathrm{p}<0.05)$, while GR remained unaffected (Fig. 3). Significant increase in expression of NFkB and GR was observed again under combined stress (Fig. 3).

\section{Discussion}

In the present study we have investigated whether chronic 21 days social isolation of male Wistar rats alters antioxidant enzymes capacity in the liver, regarding both antioxidant enzyme expression and activity, and whether these alterations could be related to their transcriptional regulators, GR and NFkB. We have also followed corticosterone level which triggers GR activity, as well as, glucose level as an immediate biomarker of GR activity in liver. We found decreased level of serum CORT and blood GLU, in chronically isolated animals compared to the control. This finding was in accordance with observations of other authors who showed hypothalamic-pituitary-adrenal axis hypoactivity in stress conditions caused by isolation (Sanchez et al. 1998, Malkesman et al. 2006). It is not surprising that decreased CORT level was accompanied by the decreased blood GLU, since this hormone is the major regulator of gluconeogenesis (Friedman et al. 1993). Moreover, we found that the GR expression under chronic isolation was indistinguishable from the control 
level, while NFkB expression was upregulated. Although NFkB elevation may result from cytokine signaling (IL-1) (Sternberg 2006), in this situation it is more likely to be a consequence of lack of its repression by GR (McKay and Cidlowsky 1999). Regarding the antioxidant enzymes, we observed the increased activity of CuZnSOD which was not matched with the corresponding activity of either of the peroxidases (CAT or GPx). Such conditions might result in accumulation of $\mathrm{H}_{2} \mathrm{O}_{2}$ which is a known activator of NFkB pathway (Kobayashi et al. 2008). Interestingly, we did not observe increase in MnSOD expression under the chronic stress. The lack of response of MnSOD and the peroxidases may also be a consequence of decreased CORT, since their expression was previously shown to be highly dependent on the presence of glucocorticoid hormones (Jose et al. 1997). Nevertheless, the activated NFkB and concomitant increase in CuZnSOD might have resulted in "vicious cycle" of $\mathrm{H}_{2} \mathrm{O}_{2}$ accumulation, perpetuating NFkB activity and $\mathrm{CuZnSOD}$ expression. This assumption was further corroborated by our finding of significant reduction in GLR level and activity, since the expression of this enzyme is known to be inhibited by increase in $\mathrm{H}_{2} \mathrm{O}_{2}$ (Gutierrez-Corea and Stoppani 1997, Seo et al. 2006). In addition, reduced GLR may be a direct consequence of low GLU, since GLU drives energy metabolism, i.e. the generation of direct GLR substrates: NADPH and reduced GSH (Singh et al. 2008, Andreyev et al. 2005). GLR is known to be an essential enzyme in regulation of overall homeostatic oxido-reductive balance in any living cell, and the lack of GLR activity was previously demonstrated in numerous clinical pathologies (Loos et al. 1976). Therefore, we concluded that chronic social isolation led to disproportion between superoxide metabolizing SODs and peroxide metabolizing enzymes (CAT, GPx) as well as GLR, thus promoting $\mathrm{H}_{2} \mathrm{O}_{2}$ accumulation and prooxidative state in liver.

The second question we asked in our study was if altered antioxidant enzyme balance in liver, set by the chronic stress, may influence the adaptive response to a subsequent stressor. To answer this question we have exploited either naive or chronically stressed animals that were challenged by $30-\mathrm{min}$ immobilization. This type of stressor was chosen due to increase in CORT, accompanied with high GLU, which confirmed the intense GCs action in response to immobilization. In naive animals exposed to immobilization, both GR and NFkB were significantly induced, although NFkB induction was somewhat more prominent than that of
GR, as compared to their respective controls. This ratio of GR vs. NFkB signals led to increase in superoxide dismutases (MnSOD, CuZnSOD), catalase (CAT) and glutathione peroxidase (GPx) which implied efficient detoxification of superoxide and $\mathrm{H}_{2} \mathrm{O}_{2}$ under these conditions. Therefore our data showed that temporary ROS overproduction under immobilization, which was also found by other authors (Davydov and Shvets 2001, Zaidi et al. 2005, Liu et al. 1994) could be efficiently surpassed by antioxidant defense within $30 \mathrm{~min}$.

When chronically isolated Wistar rats were exposed to immobilization, as a subsequent stress in the combined stress model, we found that both CORT and GLU were elevated. Compared to response of naive animals to acute immobilization, the chronically stressed animals subjected to the same stressor, exhibited exaggerated CORT and GLU response. Under combined stress we have found elevated levels of both transcription factors (TFs), similar to those observed under acute stress. The levels of CuZnSOD and CAT proteins/activities were increased, thus providing ROS detoxification cascade under combined stress. However, the levels/activities of MnSOD and GPx remained unaffected showing the lack of antioxidant enzyme response at this level. It may be of special interest to mention that GPx was not restored in spite of the prominent increase in the level of GLR activity. However, since the amplitude of GLR increase was much higher than under the acute stress, it might have indicated that upon twofold GLU increase the system was striving to recuperate from oxido-reductive imbalance induced by the chronic isolation. Taken together, the results of the combined stress model suggested that in spite of restored levels of CORT, GLU and TFs, the restoration of oxidoreductive balance might have been only partial due to irreversible alterations in antioxidant enzyme set by the previous chronic stress experience.

According to currently available literature, our study is the second one providing the data which may help to understand mechanistic aspects of conversion of chronic neuroendocrine, i.e. psychosocial stress into cellular dysfunctions in the distant target tissues such as liver (Bierhaus et al. 2003). Although partly reversible, the alterations in TFs and antioxidant defense parameters such as those described in our study may compromise normal liver functions or aggravate preexisting liver diseases. Also, it may be expected that the recuperating ability of liver cells, regarding TFs signaling and antioxidant defense, might be gradually lost provided the 
chronic stress is prolonged beyond their limits. Finally, our finding may be of importance regarding the fact that most of stress-related disorders of CNS are treated with drugs activated by the liver enzymes (Mandrioli et al. 2006). Thus, the functional state of liver antioxidant defense mechanisms has to be taken into account if any side effects of drug treatment potentially compromising normal liver functions are to be avoided.

\section{Conflict of Interest}

There is no conflict of interest.

\section{Acknowledgements}

We gratefully acknowledge the Ministry of Sciences of the Republic of Serbia (Grant ON143042B) for financial support of the study.

\section{References}

ANDREYEV AY, KUSHNAREVA YE, STARKOV AA: Mitochondrial metabolism of reactive oxygen species. Biochemistry (Mosc) 70: 200-214, 2005.

ANTRAS-FERRY J, MAHEEO K, MOREL F, GUILLOUZO A, CILLARD P, CILLARD J: Dexamethasone differently modulates TNF- $\alpha$ - and IL- $1 \beta$-induced transcription of the hepatic Mn-superoxide dismutase gene. FEBS Lett 403: 100-104, 1997.

BIERHAUS A, WOLF J, ANDRASSY M, ROHLEDER N, HUMPERT PM, PETROV D, FERSTL R, VON EYNATTEN M, WENDT T, RUDOFSKY G, JOSWIG M, MORCOS M, SCHWANINGER M, MCEWEN B, KIRSCHBAUM C, NAWROTH PP: A mechanism converting psychosocial stress into mononuclear cell activation. Proc Natl Acad Sci USA 100: 1920-1925, 2003.

CLAIBORNE A: Catalase activity. In: Handbook of Methods for Oxygene Radical Research. GREENWALD RA (ed), CRC Press, Boca Raton, FL, 1985, pp 283-284.

DAVYDOV VV, SHVETS VN: Lipid peroxidation in the heart of adult and old rats during immobilization stress. Exp Gerontol 36: 1155-1160, 2001.

DE BOSSCHER K, VANDEN BERGHE W, HAEGEMAN G: The interplay between the glucocorticoid receptor and nuclear factor- $\mathrm{KB}$ or activator protein-1: molecular mechanisms for gene repression. Endocrine Rev 24: 488-522, 2003.

FINKEL T, HOLBROOK NJ: Oxidants, oxidative stress and the biology of ageing. Nature 408: 239-247, 2000.

FRIEDMAN JE, YUN JS, PATEL YM, MCGRANE MM, HANSON RW: Glucocorticoids regulate the induction of phosphoenolpyruvate carboxykinase (GTP) gene transcription during diabetes. J Biol Chem 268: 12952-12957, 1993.

GARCIA A, MARTI O, VALLES A, DAL-ZOTTO S, ARMARIO A: Recovery of the hypothalamic-pituitary-adrenal response to stress. Effect of stress intensity, stress duration and previous stress exposure. Neuroendocrinology $\mathbf{7 2}$ : 114-125, 2000.

GLATZLE D, VUILLEUMIER JP, WEBER F, DECKER K: Glutathione reductase test with whole blood, a convenient procedure for the assessment of the riboflavin status in humans. Experientia 30: 665-667, 1974.

GUTIERREZ-CORREA J, STOPPANI AO: Inactivation of yeast glutathione reductase by Fenton systems: effect of metal chelators, cateholamines and thiol compounds. Free Radic Res 27: 543-555, 1997.

JOSE HJ, BERENICE SG, CECILIA VR: Induction of antioxidant enzymes by dexamethasone in the adult rat lung. Life Sci 60: 2059-2067, 1997.

KIM HT, KIM YH, NAM JW, LEE HJ, RHO HM, JUNG G: Study of 5V-flanking region of human Cu/Zn superoxide dismutase. Biochem Biophys Res Commun 201: 1526-1533, 1994.

KOBAYASHI Y, NISHIKAWA M, HYOUDOU K, YAMASHITA F, HASHIDA M: Hydrogen peroxide-mediated nuclear factor $\mathrm{\kappa B}$ activation in both liver and tumor cells during initial stages of hepatic metastasis. Cancer Sci 99: 1546-1552, 2008.

KVETŇANSKÝ R, MIKULAJ L: Adrenal and urinary catecholamines in rat during adaptation to repeated immobilization stress. Endocrinology 87: 1868-1874, 1970.

LAEMMLI UK: Cleavage of structural proteins during the assembly of the head of bacteriophage T4. Nature 227: 680$685,1970$. 
LIU J, WANG X, MORI A: Immobilization stress-induced antioxidant defense changes in rat plasma: effect of treatment with reduced glutathione. Int J Biochem 26: 511-517, 1994.

LOOS H, ROOS D, WEENING R, HOUWERZIJL J: Familial deficiency of glutathione reductase in human blood cells. Blood 48: 53-62, 1976.

LOWRY OH, ROSEBROUGH NJ, FARR AL, RANDALL RJ: Protein measurement with the Folin phenol reagent. $J$ Biol Chem 193: 265-275, 1951.

MALKESMAN O, MAAYAN R, WEIZMAN A, WELLER A: Aggressive behavior and HPA axis hormones after social isolation in adult rats of two different genetic animal models for depression. Behav Brain Res 175: 408-414, 2006.

MANDRIOLI R, FORTI GC, RAQQI MA: Fluoxetine metabolism and pharmacological interactions: the role of cytochrome P450. Curr Drug Metab 7: 127-133, 2006.

MARAL J, PUGET K, MICHELSON AM: Comparative study of superoxide dismutase, catalase and glutathione peroxidase levels in erythrocytes of different animals. Biochem Biophys Res Commun 77: 1525-1535, 1977.

MARTINDALE JL, HOLBROOK NJ: Cellular response to oxidative stress: signalling for suicide and survival. $J$ Cell Physiol 192: 1-15, 2002.

MCCORD JM, FRIDOVICH I: Superoxide dismutase. An enzyme function for erythrocuprein (hemocuprein). $J$ Biol Chem 224: 6049-6055, 1969.

MCEWEN BS: Protective and damaging effects of stress mediators: central role of the brain. N Engl J Med 338: 171-179, 1998.

MCINTOSH LJ, HONG KE, SAPOLSKY RM: Glucocorticoids may alter antioxidant enzyme capacity in the brain: baseline studies. Brain Res 791: 209-214, 1998.

MCKAY LI, CIDLOWSKI JA: Corticosteroids. In: Cancer Medicine. BAST RC (ed), Decker, Hamilton, vol. 54, 2000, pp 730-742.

MCKAY LI, CIDLOWSKI JA: Molecular control of immune/inflammatory responses: interactions between nuclear factor- $\kappa \mathrm{B}$ and steroid receptor-signalling pathways. Endocrine Rev 20: 435-459, 1999.

NAVARRO-AREVALO A, SANCHEZ-DEL-PINO MJ: Age and exercise-related changes in lipid peroxidation and superoxide dismutase activity in liver and soleus muscle tissues of rats. Mech Ageing Dev 104: 91-102, 1998.

ROJO AI, SALINAS M, MARTIN D, PERONA R, CUADRADO A: Regulation of Cu/Zn-superoxide dismutase

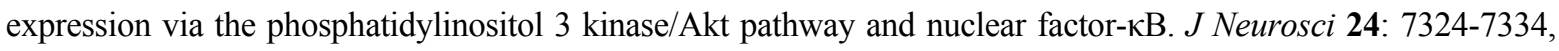
2004.

SANCHEZ MM, AGUADO F, SANCHEZ-TOSCANO F, SAPHIER D: Neuroendocrine and immunocytochemical demonstrations of decreased hypothalamo-pituitary-adrenal axis responsiveness to restraint stress after long-term social isolation. Endocrinology 139: 579-587, 1998.

SAPOLSKY RM, ROMERO ML, MUNCK AU: How do glucocorticoids influence stress responses? Integrating permissive, suppressive, stimulatory, and preparative actions. Endocr Rev 21: 55-89, 2000.

SEO JS, LEE KW, RHEE JS, HWANG DS, LEE YM, PARK HG, AHN IY, LEE JS: Environmental stressors (salinity, heavy metals, $\mathrm{H}_{2} \mathrm{O}_{2}$ ) modulate expression of glutathione reductase (GR) gene from the intertidal copepod Tigriopus japonicus. Aquat Toxicol 80: 281-289, 2006.

SINGH R, LEMIRE J, MAILLOUX RJ, APPANNA VD: A novel strategy involved in anti-oxidative defense: the conversion of NADH into NADPH by a metabolic network. PLoS One 3: e2682, 2008.

STERNBERG EM: Neural regulation of innate immunity: a coordinated nonspecific host response to pathogens. Nat Rev Immunol 6: 318-328, 2006.

WAN XS, DEVALARAJA MN, ST.CLAIR DK: Molecular structure and organization of the human manganese superoxide dismutase gene. DNA Cell Biol 13: 1127-1136, 1994.

XU Y, KININGHAM KK, DEVALARAJA MN, YEH CC, MAJIMA H, KASARSKIS EJ, ST.CLAIR DK: An intronic $\mathrm{NF}-\kappa \mathrm{B}$ element is essential for induction of the human manganese superoxide dismutase gene by tumor necrosis factor- $\alpha$ and interleukin-1 $\beta$. DNA Cell Biol 18: 709-722, 1999.

ZAIDI SM, AL-QIRIM TM, BANU N: Effects of antioxidant vitamins on glutathione depletion and lipid peroxidation induced by restraint stress in the rat liver. Drugs $R$ D 6: 157-165, 2005.

ZHOU LZ, JOHNSON AP, RANDO TA: NFאB and AP-1 mediate transcriptional responses to oxidative stress in skeletal muscle cells. Free Radic Biol Med 31: 1405-1416, 2001. 